\begin{tabular}{|c|c|c|}
\hline (1) & $\begin{array}{c}\text { Türkiye Tarımsal Araştırmalar Dergisi } \\
\text { dergipark.org.tr/tutad }\end{array}$ & $\begin{array}{l}\text { Turk J Agric Res } \\
\text { 2020, 7(1): 96-104 } \\
\text { @ TÜTAD } \\
\text { ISSN: 2148-2306 }\end{array}$ \\
\hline $\begin{array}{l}\text { ÜNIVERSITESI } \\
\text { Bilimin Yüumuda }\end{array}$ & Research Article & $\begin{array}{l}\text { e-ISSN: } 2528-858 \mathrm{X} \\
\text { doi: } 10.19159 / \text { tutad.673602 }\end{array}$ \\
\hline
\end{tabular}

\title{
Induction of Anthocyanin Accumulation in Callus Culture of 'Karaerik' (Vitis vinifera L.) by Ultraviolet Irradiation Effect ${ }^{*}$
}

\author{
Dilhem OĞUZ ${ }^{1}$, Nurhan KESKIIN ${ }^{2 * *}$, Fethi Ahmet ÖZDEMIIR ${ }^{3}$ \\ ${ }^{I}$ Van Yüzüncü Yll University, Graduate School of Natural and Applied Sciences, Department of Horticulture, Van, TURKEY \\ ${ }^{2}$ Van Yüzüncü Yll University, Faculty of Agriculture, Department of Horticulture, Van, TURKEY \\ ${ }^{3}$ Bingöl University, Faculty of Science and Art, Department of Molecular Biology and Genetics, Bingöl, TURKEY
}

\begin{tabular}{|c|c|}
\hline Received: 11.01 .2020 & Accepted: 27.02 .2020 \\
\hline \multicolumn{2}{|l|}{ ORCID ID (by author order) } \\
\hline (1D) orcid.org/0000-0002-2522-0857 (1) orcid.org/0000-0003-23 & cid.org/0000-0003-0862-9690 \\
\hline
\end{tabular}

\begin{abstract}
In this study, the effect of ultraviolet (UV) irradiation on the induction of anthocyanin production in callus cultures of 'Karaerik' grape cultivar was investigated. The most appropriate callus tissues were obtained from the leaves of the cuttings grown in in vitro plants. Gamborg B-5 medium containing 3 combinations of NAA (naphthalene acetic acid), and Kin (kinetin) was used. Callus tissues were subcultured two times with 21 days intervals. After the second subculture, 12 and 15 day old callus tissues were exposed to $254 \mathrm{~nm}$ UV-C light at $10 \mathrm{~cm}$ distance from the source for 10 and 15 min by opening covers of the petri dishes in the sterile cabin. After the treatment, callus tissues were incubated under dark conditions. Anthocyanin values were measured at $0,24^{\text {th }}, 48^{\text {th }}$ and $72^{\text {nd }}$ hours by spectrophotometer. It has been determined that UV radiation is effective for the induction of anthocyanin production in grape tissues. The highest anthocyanin production $\left(196.74 \mu \mathrm{mol} \mathrm{g}^{-1} \mathrm{FW}\right)$ was obtained from 12 day old calli grown in the first medium for a 72 -hour incubation period after 10 min UV irradiation.
\end{abstract}

Keywords: Grapevine, plant tissue culture, elicitor, secondary metabolite, abiotic stress

\section{Introduction}

One of the basic systems that are employed in the plant cell and tissue culture to production of the secondary metabolites are callus cultures. Callus cultures may be described as the masses that have morphological irregularities are resulted from culturing organs or tissue fragments cut off from parent plants after losing their ability to divide under in vitro conditions. The origin of the tissue fragment used is important for the production of secondary metabolites (Sökmen and Gürel, 2001; Keskin and Kunter, 2007, 2008, 2009, 2010).

It is known that environmental and nutritional factors are effective in the biosynthesis of secondary metabolites. Plant cells and tissue cultures, the nutritional factors that exist in the culture medium, in other words, carbon, phosphorus, nitrogen sources and other macroelements and plant growth regulators, namely, auxin and cytokines, affect differentiation in to organogenesis and metabolite formation in cells or tissues. Also, environmental factors affect the production of secondary metabolites in vitro directly or indirectly. On the other hand all of these factors have been effected by the plant and the culture type. (Gundlach et al., 1992; Sökmen and Gürel, 2001; Bhagyalakshmi et al., 2004; Matkowski, 2008).

In plant cells and tissue cultures, the physical conditions, as well as the chemical components of the culture medium, affect the production and accumulation of secondary metabolites. Among the physical conditions, light and temperature are the most important factors (Harborne, 2001; Sökmen and Gürel, 2001; Stintzing and Carle, 2004; Canturk et al., 2018). In the Prunus cerasus callus and suspension culture, the light factor caused the color of the exposed tissues turned into white (Blando et al., 2005).

\footnotetext{
": This study was summarized from the MSc. Thesis of first author's entitled "Inducing of Anthocyanin in Callus Culture of Karaerik by Effect of UV Irradiation" at Graduate School of Natural and Applied Sciences, Van Yüzüncü Yıl University.
} 
Biotic and abiotic elicitors are used for increasing secondary metabolite synthesis in plant cells and tissue cultures, ensuring production in high concentrations in shorter times (Barz et al., 1988). One of the most significant aspects of secondary metabolites is to develop in response to stress factors (Grassman et al., 2002). To obtain high amounts of secondary metabolites, plants should be exposed to stress factors during biosynthesis (Verporte et al., 2002; Mulabagal and Tsay, 2004).

Polysaccharides, proteins, glycoproteins, bacteria, fungi and yeast-derived biotic elicitors, as well as abiotic elicitors from environmental factors such as ultraviolet (UV), heavy metal ions, as well as biotic elicitors such as jasmonic acid / methyl jasmonate, salicylic acid and hydrogen peroxide are applied as elicitor in the synthesis of various secondary metabolites (Sökmen and Gürel, 2001; Matkowski, 2008).

Production of secondary metabolites with plant cell and tissue culture systems may be carried out with faster, simpler, more reliable and more predictable methods compared to conventional methods. In recent years, studies on obtaining secondary metabolites with plant cell and tissue culture systems have gained speed (Eibl et al., 2018; Cardoso et al., 2019).

The purpose of this study was to stimulate and determine the anthocyanin production by using the revealing effect of UV irradiation and with callus culture method in grapevine (Vitis vinifera L.), which can produce anthocyanin, a valuable secondary metabolite; and to determine the anthocyanin production potential of the 'Karaerik' grape cultivar.

\section{Materials and Methods}

\subsection{Material}

As the material of the study, one year old canes of 'Karaerik' grape cultivar, which is the only standard table grape cultivar of Northeastern Agricultural Region, were used. The canes obtained from the pruning period of 2016 and 2017 and were maintained in a climate chamber at $25{ }^{\circ} \mathrm{C}$ under $16 / 8$ hours photoperiod.

\subsection{Obtaining in vitro shoots}

The explants contained single node from the shoots that were obtained by maintaining canes in a climate chamber, were disinfected for $15 \mathrm{~min}$ by using a $10 \%$ sodium hypochlorite solution $(0.5 \%$ $\mathrm{NaOCl}$ ) with $1-2$ drops $0.01 \%$ Tween 20 . After the disinfection, the materials were rinsed 3 times with sterile distilled water for at least $5 \mathrm{~min}$ each. To obtain in vitro plantlets, MS (Murashige and Skoog, 1962) semisolid basic nutrient media was used. The $\mathrm{pH}$ of the medium was prepared by adding $4.4 \mathrm{~g}$ MS basal medium (Sigma) per liter and adjusted to 5.7. A total of $1.0 \mathrm{mg} \mathrm{L}^{-1} \mathrm{BAP}$ (6-benzylaminopurine) was added as the growthregulating agent to enhance the growth of the shoots. The nutrient media were supplemented with sucrose (3\%) and agar $(6 \%)$ and sterilized in an autoclave for $20 \mathrm{~min}$ at $121{ }^{\circ} \mathrm{C}$. The single-node explants were cultured and incubated at $8 / 16$ photoperiod at $25^{\circ} \mathrm{C}$. Then in vitro plantlets were obtained by continuing the sub-culturation process with an interval of 21 days until providing adequate explant for the study.

\subsection{Establishing the callus cultures}

In callus cultures, B5 (Gamborg et al., 1968) basic nutrient medium was used. The $\mathrm{pH}$ value of the nutrient medium was prepared by adding $3.2 \mathrm{~g}$ ready nutrient medium to pure water and adjusted to 5.7. Three different combinations were prepared as the growth-regulating agent. For the first combination, $0.1 \mathrm{mg} \mathrm{L}^{-1} \mathrm{NAA}$ and $0.2 \mathrm{mg} \mathrm{L}^{-1} \mathrm{Kin}$ (Mihai et al., 2009; Mihai et al., 2010) were added; for the second combination, $5 \mathrm{mg} \mathrm{L}^{-1} \mathrm{NAA}$ and $1 \mathrm{mg} \mathrm{L}^{-1}$ Kin were added (Tamura et al., 1989); and for the third combination, $2 \mathrm{mg} \mathrm{L}^{-1} \mathrm{NAA}$ and $0.5 \mathrm{mg} \mathrm{L}^{-1}$ Kin (Lazăr et al., 2013) were added. Then, sucrose $(30 \%)$ and agar $(0.8 \%)$ were added to the nutrient medium and sterilized in an autoclave at $121{ }^{\circ} \mathrm{C}$ for $20 \mathrm{~min}$. As the callus initial explant, the leaf blades obtained from the in vitro plantlets were used. The cultures were taken to the sub-culture twice with 21 days intervals, and callus multiplication was ensured.

\subsection{Elicitor application}

Short-wave UV-C light was used as an elicitor. The UV-C (Vilber-Lourmat T-15C $254 \mathrm{~nm}$ ) light was applied to the cultures for two different periods from $10 \mathrm{~cm}$ distance for 10 and $15 \mathrm{~min}$. For this purpose, the application was carried out to the 12 and 15 day old cultures by opening the lids of the Petri dishes in the sterile cabin.

\subsection{Determining the anthocyanin content}

Anthocyanin content was determined by modifying the method of Tarrahi and Rezanejad (2013). A total of $0.5 \mathrm{~g}$ fresh callus was homogenized at $10 \mathrm{ml}$ acidic methanolic solution (99:1, Methanol: $\mathrm{HCl}$ ), and was kept at $+25^{\circ} \mathrm{C}$ for 24 hours. The supernatant of the samples was centrifuged at $4000 \mathrm{rpm}$ for $12 \mathrm{~min}$ and absorbance was measured at $550 \mathrm{~nm}$ in a spectrophotometer. Anthocyanin content was calculated using the 
extinction coefficient $(\epsilon)$ of $33.000 \mathrm{~cm}^{-1} \mathrm{~mol}^{-1}$ and based on the following Equation 1:

$$
\mathrm{A}=\epsilon \mathrm{bc} \text {, }
$$

Where absorbance $=A$, cell width $=1 \mathrm{~cm}=\mathrm{b}$, and anthocyanin concentration $=$ c. Total anthocyanin content was determined as $\mu \mathrm{mol} \mathrm{g} \mathrm{g}^{-1}$ FW (fresh weight). The anthocyanin content was calculated as cyanidin-3-glycoside.

\subsection{Statistical analysis}

Descriptive statistics for the anthocyanin content are presented as Mean and Standard Deviations. To determine whether there are differences between the application times (10 and $15 \mathrm{~min}$ ), callus ages (12 and 15 day old), incubation times $(0,24,48$ and 72 hours) and the media ( $1^{\text {st }}, 2^{\text {nd }}$ and $3^{\text {rd }}$ medium combinations), the "Repeated Measures Analysis of Variance in Factorial Design" was applied. Following the Variance Analysis, the Duncan's multiple range test was used to determine the different groups. The statistical significance level was considered as 5\% and the IBM SPSS (ver:21) Statistical Package software was used for all statistical analysis.

\section{Results and Discussion}

According to the results of the factorial variance analysis, since the interactions were found to be statistically significant, the comparisons were performed at the subgroups level. For avoiding complication, no lettering was done for nonsignificant factors in Table 1. Descriptive statistics and the results of the comparisons for anthocyanin content are given in Table 1.

Firstly, when Table 1 is examined for the media combinations, it is clear that the difference between the media in all incubation periods was statistically significant in the $10 \mathrm{~min} U \mathrm{UV}$-treated 12 day old calli, and the difference between the media was also at a statistically significant level in the 10 min UV irradiation in 72 hours' incubation time in 15 day old calli $(p<0.05)$. In addition, in 12 day old calli to which 15 min UV was applied, the difference was found to be significant; and in the 15 day old calli to which UV was applied for 15 min at the $48^{\text {th }}$ hour of the incubation, the difference was found to be statistically significant at the $24^{\text {th }}$ hour $(\mathrm{p}<0.05)$. The highest anthocyanin content, $84.31 \mu \mathrm{mol} \mathrm{g}{ }^{-1} \mathrm{FW}$, which was the highest anthocyanin content at the $0^{\text {th }}$ hour, and which was the control of the 12 day old calli, was measured at the $3^{\text {rd }}$ medium combination, and the lowest one

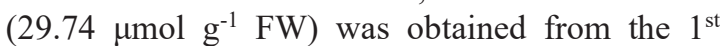
medium combination. At the end of the 24-hour incubation period, the highest content (161.51 $\mu$ mol g ${ }^{-1}$ FW) was measured at the $2^{\text {nd }}$ medium combination, and the difference between the $1^{\text {st }}$ and $3^{\text {rd }}$ combinations was not found to be statistically significant. At the $48^{\text {th }}$ and $72^{\text {nd }}$ hour incubation periods, the highest anthocyanin production was measured at the $1^{\text {st }}$ combination (130.83 $\mu \mathrm{mol} \mathrm{g}{ }^{-1} \mathrm{FW}$ and $196.74 \mu \mathrm{mol} \mathrm{g}{ }^{-1} \mathrm{FW}$, respectively). Although the difference between the $3^{\text {rd }}$ medium combination at the $48^{\text {th }}$ hour and the two other combinations was not found to be statistically significant, the difference between all combinations was found to be statistically significant at $72^{\text {nd }}$ hour $(\mathrm{p}<0.05)$. When $10 \mathrm{~min}$ UV was applied to 15 day old calli, the highest content was measured at the $1^{\text {st }}$ combination with 167.72 $\mu \mathrm{mol} \mathrm{g}{ }^{-1} \mathrm{FW}$, and the lowest one was measured at the $2^{\text {nd }}$ combination with $74.69 \mu \mathrm{mol} \mathrm{g}^{-1} \mathrm{FW}$; and the difference of the $3^{\text {rd }}$ combination was not found to be significant compared to two other applications (Table 1)

Although the difference between the 48-hour application in which $15 \mathrm{~min}$ UV was applied to 12 day old calli and the $2^{\text {nd }}$ and $3^{\text {rd }}$ medium combinations at the $24^{\text {th }}$ hour incubation time was not found to be statistically significant, the highest anthocyanin content was obtained from the $3^{\text {rd }}$ medium combination. The values obtained from the first medium combination were the lowest among the mentioned incubation times.

When Table 1 is evaluated in terms of incubation time, the difference between incubation time in all media combinations in 12 day old calli for 10 min irradiation was found to be statistically significant; however, only the difference between the incubation time was found to be significant in terms of $3^{\text {rd }}$ medium combination when 10 and 15 min UV were applied to 15 day old $(\mathrm{p}<0.05)$. The highest value was determined as $196.74 \mu \mathrm{mol} \mathrm{g}{ }^{-1}$ FW at the $72^{\text {nd }}$ hour in the $1^{\text {st }}$ medium combination when 10 min UV was applied to 12 day old calli, and the lowest value was determined as 29.74 $\mu \mathrm{mol} \mathrm{g} \mathrm{g}^{-1} \mathrm{FW}$ from the control calli although the difference from the $24^{\text {th }}$ hour was not significant. Similarly, although the difference from the $72^{\text {nd }}$ hour was not statistically significant in the $2^{\text {nd }}$ medium combination, the highest value was determined as $161.51 \mu \mathrm{mol} \mathrm{g}{ }^{-1} \mathrm{FW}$ at the $24^{\text {th }}$ hour. Again, although the difference was not statistically significant compared to the $48^{\text {th }}$ hour, the lowest value was obtained as $69.01 \mu \mathrm{mol} \mathrm{g}{ }^{-1} \mathrm{FW}$ in the control calli. In the $3^{\text {rd }}$ medium combination, although the result was not different from the $72^{\text {nd }}$ hour at a significant level, the highest value was obtained at the $48^{\text {th }}$ hour with $118.18 \mu \mathrm{mol} \mathrm{g}^{-1} \mathrm{FW}$; the lowest value was obtained in the control calli with $84.31 \mu \mathrm{mol} \mathrm{g}{ }^{-1} \mathrm{FW}$, and at the $24^{\text {th }}$ hour with $89.91 \mu \mathrm{mol} \mathrm{g}^{-1} \mathrm{FW}$. When $10 \mathrm{~min} \mathrm{UV}$ was applied 
Table 1. Descriptive statistics and comparison results in terms of anthocyanin content $\left(\mu \mathrm{mol} \mathrm{g} \mathrm{g}^{-1} \mathrm{FW}\right)$

\begin{tabular}{|c|c|c|c|c|c|c|c|c|c|}
\hline & & \multicolumn{8}{|c|}{12 day old calli } \\
\hline & & \multicolumn{2}{|c|}{$0 \mathrm{~h}$} & \multicolumn{2}{|l|}{$24 \mathrm{~h}$} & \multicolumn{2}{|l|}{$48 \mathrm{~h}$} & \multicolumn{2}{|c|}{$72 \mathrm{~h}$} \\
\hline $\begin{array}{l}\text { Time } \\
(\mathrm{min})\end{array}$ & Medium & Mean & SD & Mean & SD & Mean & SD & Mean & SD \\
\hline \multirow{3}{*}{10} & 1 & $29.74 \mathrm{Bc} \phi$ & 1.84 & $67.27 \mathrm{Bc} \neq \phi$ & 2.61 & $130.83 \mathrm{Ab \phi}$ & 24.16 & $196.74 \mathrm{Aa}$ & 9.72 \\
\hline & 2 & $69.01 \mathrm{Ab \phi}$ & 6.16 & $161.51 \mathrm{Aa}$ & 35.62 & $70.98 \mathrm{Bb} \neq$ & 9.05 & 132.27 Bał $\phi$ & 5.11 \\
\hline & 3 & $84.31 \mathrm{Ab \phi}$ & 5.54 & $89.91 \mathrm{Bb}$ & 4.06 & $118.18 \mathrm{ABa} \phi$ & 8.39 & $101.81 \mathrm{Cab}$ & 10.81 \\
\hline \multirow{5}{*}{15} & 1 & $35.74 \mathrm{Bb} \phi$ & 1.84 & $136.59 \mathrm{a} \phi$ & 6.30 & $69.09 \mathrm{Bb}$ & 14.73 & $135.45 \mathrm{a}$ & 32.97 \\
\hline & 2 & $63.01 \mathrm{~A} \phi$ & 6.16 & 136.81 & 40.19 & $128.33 \mathrm{~A}$ & 17.06 & 85.07 & 5.08 \\
\hline & 3 & $80.31 \mathrm{Ab} \phi$ & 5.54 & $78.48 \mathrm{~b}$ & 4.89 & $150.53 \mathrm{Aa} \phi$ & 17.43 & $146.36 \mathrm{a}$ & 25.72 \\
\hline & & \multicolumn{8}{|c|}{15 day old calli } \\
\hline & & \multicolumn{2}{|c|}{$0 \mathrm{~h}$} & \multicolumn{2}{|c|}{$24 \mathrm{~h}$} & \multicolumn{2}{|l|}{$48 \mathrm{~h}$} & \multicolumn{2}{|c|}{$72 \mathrm{~h}$} \\
\hline $\begin{array}{l}\text { Time } \\
\text { (min) }\end{array}$ & Medium & Mean & SD & Mean & SD & Mean & SD & Mean & SD \\
\hline \multirow{3}{*}{10} & 1 & 71.36 & 10.44 & $97.88 \neq$ & 4.78 & 134.01 & 46.07 & $167.72 \mathrm{~A} \neq$ & 31.98 \\
\hline & 2 & 94.09 & 6.86 & 94.01 & 11.62 & 107.95 & 15.14 & $74.69 \mathrm{~B}$ & 11.49 \\
\hline & 3 & $68.86 \mathrm{~b}$ & 2.74 & $99.87 \mathrm{~b}$ & 9.36 & $69.01 \mathrm{~b}$ & 7.93 & $119.69 \mathrm{ABa}$ & 5.89 \\
\hline \multirow{3}{*}{15} & 1 & 70.63 & 10.44 & $45.75 \mathrm{~B}$ & 4.94 & 127.95 & 44.83 & 66.06 & 16.27 \\
\hline & 2 & 92.07 & 6.86 & $78.41 \mathrm{~A}$ & 3.67 & 95.00 & 5.52 & 87.57 & 9.39 \\
\hline & 3 & 66.16 & 2.74 & $86.74 \mathrm{~A}$ & 1.51 & 71.13 & 20.55 & 108.56 & 15.07 \\
\hline
\end{tabular}

a, b, c: $\rightarrow$ The differences between the means reprepresented by different lower case in the the same callus age, application time and incubation times are statististically significant [comparison of incubation times] $(\mathrm{p}<0.05)$

A, B, C: $\downarrow$ The differences between the means reprepresented by different upper case in the same callus age, irradiation and the incubation time are statististically significant [comparison of media] $(p<0.05)$

‡: The difference from $15 \mathrm{~min}$ irradiation in the same callus age and media is statistically significant [comparison of irradiation time] $(\mathrm{p}<0.05)$

$\phi$ : The difference from 15 day old calli in the same media, incubation time, application time is statistically significant [comparison of the ages of the calli] $(\mathrm{p}<0.05)$, SD: Standard deviation

to 15 day old calli, the difference between the incubation times was found to be statistically significant only in the $3^{\text {rd }}$ medium combination, and the highest value was obtained at the $72^{\text {nd }}$ hour with $119.69 \mu \mathrm{mol} \mathrm{g}^{-1} \mathrm{FW}$. The differences between the other incubation times were not found to be statistically significant. Although the difference from the $72^{\text {nd }}$ hour was not significant at the 15 min UV application to 12 day old calli, the highest value $\left(150.53 \mu \mathrm{mol} \mathrm{g}^{-1} \mathrm{FW}\right)$ was obtained at the $48^{\text {th }}$ hour. The difference from the control calli was not statistically significant, and the lowest value was obtained at the $24^{\text {th }}$ hour with $78.48 \mu \mathrm{mol} \mathrm{g}{ }^{-1}$ FW (Table 1).

When Table 1 is evaluated in terms of UV application times, it can be noted that the difference between the application times was found to be statistically significant at the $24^{\text {th }}$ hour of the 12 day old calli at the $1^{\text {st }}$ medium combination, and at the $48^{\text {th }}$ and $72^{\text {nd }}$ hour of the $2^{\text {nd }}$ medium combination. Only the difference between the application times at the $24^{\text {th }}$ and $72^{\text {nd }}$ hours was found to be statistically significant at the 15 day old calli in the $1^{\text {st }}$ medium combination $(p<0.05)$. In terms of the differences between the above-mentioned differences in the 12 day old calli, the $10 \mathrm{~min}$ application values were found to be lower than those of 15 min values, and the 10 min values were found to be higher than those of the 15 min values in 15 day old calli (Table 1 ).
When Table 1 is evaluated in terms of incubation times, the difference between 12 and 15 day old calli was found to be statistically significant in all medium combinations in the control calli in 10- and 15-min UV applications $(p<0.05)$. The difference between the ages of the calli was found to be significant only in the $1^{\text {st }}$ combination after 24 hours with the 10- and 15min UV application. When the incubation time at the $48^{\text {th }}$ hour was evaluated, the difference between the $1^{\text {st }}$ and $3^{\text {rd }}$ medium combinations of the $10 \mathrm{~min}$ UV application, and the difference between the 12 day old and 15 day old calli in the $3^{\text {rd }}$ medium combination in the $15 \mathrm{~min}$ UV application were found to be statistically significant $(p<0.05)$. Finally, at the $72^{\text {nd }}$ hour in Table 1, only the difference between the incubation times of the $2^{\text {nd }}$ combination in the 10 min UV application was found to be statistically significant $(\mathrm{p}<0.05)$.

The anthocyanin value of the 12 day old calli in the $1^{\text {st }}$ and $2^{\text {nd }}$ medium combinations that were exposed to 10 and $15 \mathrm{~min}$ UV was found to be lower than that of the 15 day old calli; however, the anthocyanin content of the 15 day old calli in the $3^{\text {rd }}$ medium combination was found to be higher. After 24-hour incubation, the anthocyanin content of the 15 day old calli that grown in the $1^{\text {st }}$ medium combination with 10 min UV irradiation were found to be higher. However, the 
anthocyanin content of the 12 day old calli that grown in the $3^{\text {rd }}$ medium combination with $15 \mathrm{~min}$ irradiation were detected to be higher. In the 10 and 15 minutes, UV irradiation in the $3^{\text {rd }}$ medium combinations, the values of the 12 day old calli was higher in terms of the anthocyanin content that were measured at the $48^{\text {th }}$ hour. The values measured in the 15 day old calli that grown in the $1^{\text {st }}$ medium combination and exposed to $10 \mathrm{~min}$ UV were higher than those that measured in 12 day old calli. However, the $72^{\text {nd }}$ hour anthocyanin content measured in the $2^{\text {nd }}$ medium combination with 10 min UV irradiation was found to be higher than the value that was measured in the 15 day old calli rather than 12 day old calli (Table 1 ).

\subsection{The effect of $U V$ application and incubation time on anthocyanin production}

\subsubsection{First medium combination}

The effects of UV application and incubation time on anthocyanin production in 12 day old calli that grown in $1^{\text {st }}$ medium combination with $0.1 \mathrm{mg}$ $\mathrm{L}^{-1} \mathrm{NAA}$ and $0.2 \mathrm{mg} \mathrm{L}^{-1} \mathrm{Kin}$ are given in Table 1.

After 10 min UV irradiation to the 12 day old calli that grown in the $1^{\text {st }}$ medium combination, the anthocyanin content, which was initially 29.74 $\mu \mathrm{mol} \mathrm{g}{ }^{-1} \mathrm{FW}$, increased ca. 2.26-times, and was measured as $67.27 \mu \mathrm{mol} \mathrm{g}{ }^{-1} \mathrm{FW}$ at $24^{\text {th }}$ hour. It was measured as $130.83 \mu \mathrm{mol} \mathrm{g}^{-1} \mathrm{FW}$ at the $48^{\text {th }}$ hour with an increase of 1.94-times; and $196.74 \mu \mathrm{mol}$ $\mathrm{g}^{-1} \mathrm{FW}$ at the $72^{\text {nd }}$ hour, which was the highest value. After the irradiation to $15 \mathrm{~min} U \mathrm{VV}$, the anthocyanin, which was initially measured as $35.74 \mu \mathrm{mol} \mathrm{g}^{-1} \mathrm{FW}$, became $136.59 \mu \mathrm{mol} \mathrm{g}^{-1} \mathrm{FW}$ at the $24^{\text {th }}$ hour with an increase of ca. 3.82-times, which was the highest anthocyanin production; and decreased to $69.09 \mu \mathrm{mol} \mathrm{g} \mathrm{g}^{-1} \mathrm{FW}$ at the $48^{\text {th }}$ hour at a rate of ca. 1.97-times; then, it approached the produced amount at the $24^{\text {th }}$ hour with an increase at a rate of ca. 1.96-times, and reached $135.45 \mu \mathrm{mol} \mathrm{g}^{-1} \mathrm{FW}$ at the $72^{\text {nd }}$ hour (Table 1).

After 10 min UV was applied to the 15 day old calli that grown in the $1^{\text {st }}$ medium combination, the anthocyanin content, which was initially 71.36 $\mu \mathrm{mol} \mathrm{g}{ }^{-1} \mathrm{FW}$, became $167.72 \mu \mathrm{mol} \mathrm{g}{ }^{-1} \mathrm{FW}$, which was the highest value with an increase of 2.35times at the $72^{\text {nd }}$ hour. Following the $15 \mathrm{~min}$ UV irradiation, the anthocyanin content, which was initially $70.63 \mu \mathrm{mol} \mathrm{g}{ }^{-1} \mathrm{FW}$, decreased to 45.75 $\mu \mathrm{mol} \mathrm{g}{ }^{-1} \mathrm{FW}$ at the $24^{\text {th }}$ hour; and increased again to $127.95 \mu \mathrm{mol} \mathrm{g}{ }^{-1} \mathrm{FW}$, which was the highest value at the $48^{\text {th }}$ hour. At the $72^{\text {nd }}$ hour, the anthocyanin content decreased to below the initial value and was recorded as $66.06 \mu \mathrm{mol} \mathrm{g}{ }^{-1} \mathrm{FW}$ (Table 1).

\subsubsection{Second medium combination}

The effects of UV irradiation and incubation time on anthocyanin production in 12 day old calli that grown in the $2^{\text {nd }}$ medium combination contained $5 \mathrm{mg} \mathrm{L}^{-1} \mathrm{NAA}$ and $1 \mathrm{mg} \mathrm{L}^{-1}$ Kin are given in Table 1.

After 10 min UV irradiation to 12 day old calli that grown in the second medium combination, the initial anthocyanin content, $69.01 \mu \mathrm{mol} \mathrm{g}{ }^{-1} \mathrm{FW}$, increased 2.34-times and reached the highest value of $161.51 \mu \mathrm{mol} \mathrm{g}{ }^{-1} \mathrm{FW}$ after $24 \mathrm{~h}$. The anthocyanin content decreased at $48^{\text {th }}$ hour and showed an increase with $132.27 \mu \mathrm{mol} \mathrm{g} \mathrm{g}^{-1} \mathrm{FW}$ at $72^{\text {nd }}$ hour. Similarly, the highest anthocyanin production (136.81 $\left.\mu \mathrm{mol} \mathrm{g} \mathrm{g}^{-1} \mathrm{FW}\right)$ was obtained at the $24^{\text {th }}$ hour after the 15 min UV irradiation (Table 1).

The anthocyanin content was recorded as 94.09

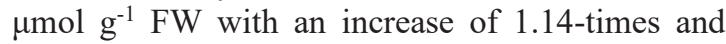
reached the highest value (compared to the initial value) at $48^{\text {th }}$ hour after 10 min UV irradiation in 15 day old calli that grew in the second medium combination; however, at the $72^{\text {nd }}$ hour, it decreased below the initial value. Similarly, the highest anthocyanin production $\left(95 \mu \mathrm{mol} \mathrm{g}{ }^{-1} \mathrm{FW}\right)$ was recorded at the $48^{\text {th }}$ hour after the $15 \mathrm{~min}$ UV irradiation, and a very small increase was recorded compared to the initial value. The value measured at the $72^{\text {nd }}$ hour was decreased below the initial value (Table 1).

\subsubsection{Third medium combination}

The effect of UV irradiation and incubation time on the anthocyanin production in 12 day old calli grown in the third medium combination that had $2 \mathrm{mg} \mathrm{L}^{-1} \mathrm{NAA}$ and $0.5 \mathrm{mg} \mathrm{L}^{-1} \mathrm{Kin}$ is given in Table 1.

After 10 min UV irradiation in 12 day old calli grown in the third medium combination, the initial anthocyanin content $84.31 \mu \mathrm{mol} \mathrm{g}{ }^{-1} \mathrm{FW}$ increased at a rate of 1.40 and was recorded as $118.18 \mu \mathrm{mol}$ $\mathrm{g}^{-1}$ FW at the $48^{\text {th }}$ hour. Similarly, the highest

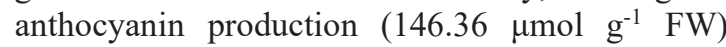
after 15 min UV irradiation increased 1.87-times at the $48^{\text {th }}$ hour (Table 1$)$.

The results of 15 day old calli that grown in the third medium combination were similar to the results of UV irradiation for 10 and $15 \mathrm{~min}$. The initial content of anthocyanin was determined as 68.86-66.16 $\mu \mathrm{mol} \mathrm{g}{ }^{-1} \mathrm{FW}$ in the calli, and it reached the highest value $\left(119.69 \mu \mathrm{mol} \mathrm{g}^{-1} \mathrm{FW}\right.$, $108.56 \mu \mathrm{mol} \mathrm{g}^{-1} \mathrm{FW}$, respectively) at the $72^{\text {nd }}$ hour after both UV irradiations (Table 1).

UV-C irradiation, which is an abiotic stress factor, is recommended as a good elicitor in 
increasing the anthocyanin production (Meng et al., 2007; Çetin et al., 2011; Khatami and Ghanati 2011; Karataş et al., 2014). In light of our findings, it would not be incorrect to argue that UV-C is a good elicitor increasing the anthocyanin production. The highest anthocyanin production was obtained at the $10 \mathrm{~min}$ UV application. Çetin et al. (2011) also reported that $10 \mathrm{~min}$ UV-C irradiation positively affected the anthocyanin production in grapevines; and that after $10 \mathrm{~min}$ UV-C irradiation, anthocyanin production increased between 4.5 and 6.5 rate compared to the control group calli.

As compared to the initial values, anthocyanin amounts increased in terms of the incubation times. In some applications, the highest value was recorded at the end of the 24-hour incubation; however, in some other applications, the highest value was recorded after the $48^{\text {th }}$ hour incubation. The highest amount of the anthocyanin that was obtained in the present study was $196.74 \mu \mathrm{mol} \mathrm{g} \mathrm{g}^{-1}$ FW at the end of an incubation period of 72 hours.

\subsection{The effect of different medium combinations on anthocyanin production}

The effect of $10 \mathrm{~min}$ UV irradiation on anthocyanin production in 12 day old calli that grown in three different media combinations is given in Table 1.

The highest anthocyanin amount was obtained in the $3^{\text {rd }}$ medium combination compared to the control calli or the initial calli at the $0^{\text {th }}$ hour, followed by combinations of $2^{\text {nd }}$ and $1^{\text {st }}$ medium combinations, respectively. The highest increase in the anthocyanin amount compared to the initial values was recorded at the 24-hour incubation in the $2^{\text {nd }}$ medium combination. The calli that were grown in the $1^{\text {st }}$ and $3^{\text {rd }}$ combinations at the $48^{\text {th }}$ hour resulted in an increase in anthocyanin production compared to the initial and 24-hour incubation period, and it was observed that the value decreased in the $2^{\text {nd }}$ medium combination. In terms of anthocyanin production, the most stable results were recorded at the first medium combination, and increases were recorded at all incubation times compared to the initial values, and the highest value of the study was found to be $196.74 \mu \mathrm{mol} \mathrm{g} \mathrm{g}^{-1} \mathrm{FW}$ at the $72^{\text {nd }}$ hour. This value was followed by $161.51 \mu \mathrm{mol} \mathrm{g} \mathrm{g}^{-1} \mathrm{FW}$ in the second medium combination in the 12 day old calli after 10 min UV irradiation at the $24^{\text {th }}$ hour.

The effect of $15 \mathrm{~min}$ UV irradiation on anthocyanin production in 12 day old calli that grown in three different media combinations is given in Table 1.
At the end of the incubation times, the anthocyanin production increased when compared to the initial values in all three media combinations; and the highest value was recorded at the $3^{\text {rd }}$ medium combination with $150.53 \mu \mathrm{mol}$ $\mathrm{g}^{-1} \mathrm{FW}$ at the $48^{\text {th }}$ hour after UV irradiation for 15 min. This value was followed by $136.81 \mu \mathrm{mol} \mathrm{g} \mathrm{g}^{-1}$ FW ( $2^{\text {nd }}$ medium combination at $24^{\text {th }}$ hour), and $136.59 \mu \mathrm{mol} \mathrm{g}{ }^{-1} \mathrm{FW}\left(1^{\text {st }}\right.$ medium combination at $24^{\text {th }}$ hour), $135.45 \mu \mathrm{mol} \mathrm{g}^{-1} \mathrm{FW}$ ( $2^{\text {nd }}$ medium combination at $72^{\text {nd }}$ hour) with close intervals.

The effect of $10 \mathrm{~min}$ UV irradiation on anthocyanin production in 15 day old calli grown in three different media combinations is given in Table 1. The anthocyanin amounts of the $1^{\text {st }}$ and $3^{\text {rd }}$ media combinations in the initial calli showed close values, and the initial anthocyanin value of the $2^{\text {nd }}$ medium combination was recorded as higher than that of the other two medium combinations. After 24 hours of the UV irradiation, at the $24^{\text {th }}$ hour, all three media showed increases in the anthocyanin value compared to the baseline values, and similarly, the values were close to each other. Similar to the results that were obtained from the 10 min UV irradiation to 12 day old calli grown in the $1^{\text {st }}$ medium combination, the results of the $10 \mathrm{~min}$ UV irradiation to 15 day old calli grown in the same medium combination showed a stable status and increased to the highest value of $167.72 \mu \mathrm{mol} \mathrm{g}^{-1} \mathrm{FW}$ in the three incubation times compared to the initial values.

The effect of 15 min UV irradiation on 15 day old calli grown in three different medium combinations is given in Table 1. It is noteworthy that anthocyanin production values were close to each other, including the initial values in all three medium combinations. The highest anthocyanin value $\left(127.95 \mu \mathrm{mol} \mathrm{g}{ }^{-1} \mathrm{FW}\right)$ was obtained at the end of the 48-hour incubation time in the calli grown in the $1^{\text {st }}$ media combination, followed by the 72-hour incubation time in the $3^{\text {rd }}$ medium combination $\left(108.56 \mu \mathrm{mol} \mathrm{g}{ }^{-1} \mathrm{FW}\right)$.

The optimization of the culture conditions is very important in the production of secondary metabolites in plant cells and tissue cultures. Abasi et al. (2012) reported that the plant growth regulators added to the medium cause increases in the phenylalanine ammonium lyase, chlorophyllase, and peroxidase enzymes, and as a result of these metabolic changes, secondary metabolite production increases. It is known that plant growth regulators affect cell division, growth, and elongation processes, and increase the secondary metabolite production in many plants. It was also reported that indole-3-butyric acid (IBA), 
indole-3-acetic acid (IAA), 1- naphthalene acetic acid (NAA), kinetin (Kin), benzyl amino purine (BA), thidiazuron (TDZ) and gibberellic acid (GA3), which are effective in the biosynthesis steps of phenolic compounds, increase the secondary metabolite amounts (Demirci et al., 2015). In the study, the highest anthocyanin production was recorded at the first medium that contained $0.1 \mathrm{mg}$ $\mathrm{L}^{-1} \mathrm{NAA}$ and $0.2 \mathrm{mg} \mathrm{L}^{-1} \mathrm{Kin}$. Similarly, since it has superiority to IAA and 2.4-D in anthocyanin production from the Glehnia littoralis, NAA was preferred as the auxin source; and when cytokine was added to the medium, the cell development and pigment biosynthesis improved (Miura et al., 1998). In another study, high NAA concentration was found to be optimal for the Rudbeckia hirta tree (Luczkiewicz and Cisowski, 2001).

\subsection{The effect of the ages of the calli on anthocyanin production}

According to the results that were obtained in the 12 and 15 day old calli, comparisons were made by considering the UV irradiation and incubation times in order to recommend the most suitable culture age because of the interaction between the factors.

\subsubsection{The first medium combination}

The results of the comparison of anthocyanin production after $10 \mathrm{~min}$ UV irradiation on 12 and 15 day old calli grown in the first medium combination are given in Table 1.

Both of two age groups of the calli grown in the first medium combination that received $10 \mathrm{~min}$ UV were found to be successful in terms of anthocyanin production. Although the 12 day old calli showed a lower amount of anthocyanin as the initial value than the 15 day old calli, the 196.74 $\mu \mathrm{mol} \mathrm{g}{ }^{-1} \mathrm{FW}$ value, which is the highest amount of anthocyanin, was recorded at the $72^{\text {nd }}$ hour, which was the final incubation time. The second highest anthocyanin production amount that was obtained in the present study $\left(167.72 \mu \mathrm{mol} \mathrm{g} \mathrm{g}^{-1} \mathrm{FW}\right)$ was obtained from 15 day old calli (Table 1 ).

The results of the comparison of anthocyanin production after $15 \mathrm{~min}$ UV irradiation to 12 and 15 day old calli grown in the first medium combination are given in Table 1 .

Although the anthocyanin production increased in the 12 day old calli grown in the first media combination with 15 min UV irradiation compared to the initial value, the anthocyanin production decreased in the 15 day old calli. This decrease was even below the initial value at the $72^{\text {nd }}$ hour, which was the last incubation time. The 12 day old calli were found to be more successful than the 15 day old calli in this combination in terms of the amount of anthocyanin production (Table 1).

\subsubsection{Second medium combination}

The results of the comparison of anthocyanin production after 10 min UV irradiation in 12 and 15 day old calli that grew in the second medium combination are given in Table 1. Although the anthocyanin production increased in the 12 day old calli that grown in the second medium combination with 10 min UV irradiation compared to the initial value, the anthocyanin production decreased in the 15 day old calli. Again, this decrease was below the initial value at the $72^{\text {nd }}$ hour, which was the last incubation time. The 12 day old calli were found to be more successful than the 15 day old calli in this combination in terms of anthocyanin production amount (Table 1).

The results of the comparison of anthocyanin production after 15 min UV irradiation in 12 and 15 day old calli cultures that grown in the second medium combination are given in Table 1 . Although the anthocyanin production in the 12 day old calli that grown in the second medium combination with 15 min UV irradiation increased compared to the initial value, the anthocyanin production decreased in the 15 day old calli. This decrease was below the initial value at the $72^{\text {nd }}$ hour, which was the last incubation time. The 12 day old calli were found to be more successful than 15 day old calli in this combination in terms of anthocyanin production (Table 1).

\subsubsection{Third medium combination}

The results of the comparison of the anthocyanin production after $10 \mathrm{~min}$ UV irradiation to 12 and 15 day old calli grown in the third medium combination are given in Table 1 . Both age groups of the calli grown in the third medium combination with 10 min UV irradiation were found to be successful in terms of anthocyanin production. The highest amount of anthocyanin production at both callus age groups was recorded nearly at the same value and was recorded as $119.69 \mu \mathrm{mol} \mathrm{g} \mathrm{g}^{-1} \mathrm{FW}$ in 15 day old calli; however, this was recorded as $118.18 \mu \mathrm{mol}$ $\mathrm{g}^{-1} \mathrm{FW}$ in 12 day old calli (Table 1 ).

The results of the comparison of the anthocyanin production after $15 \mathrm{~min}$ UV irradiation to 12 and 15 day old calli grown in the third medium combination are given in Table 1 . The 12 day old calli were found to be more successful than the 15 day old calli in terms of anthocyanin production content in this combination, and the highest anthocyanin content was measured as $150.53 \mu \mathrm{mol} \mathrm{g}^{-1} \mathrm{FW}$. 
The success in plant secondary metabolite production by using callus culture changes according to plant, culture type and age of the culture (Sökmen and Gürel, 2001). Tamura et al. (1989) measured the anthocyanin content in 40 day old calli, Mihai et al. (2009) in 30 day old, Çetin et al. (2011) in 12 day old calli, Iercan and Nedelea (2012), 36 day old calli, Lazăr et al. (2013) in 6, $12,18,24,30$ and 36 day old calli. The results of the present study are in line with the results reported by Çetin et al. (2012). However, Lazăr et al. (2013) found that 24 day old calli were more successful than 12 day old calli.

\section{Conclusions}

Anthocyanins, which are valuable secondary metabolites, are very useful compounds for both plant and human health. Grapevines have the potential of producing anthocyanins. This potential can be enhanced by biotic and abiotic elicitors. In the present study, anthocyanin production was induced and determined by UV irradiation. The results showed that as a valuable secondary metabolite, anthocyanin production can be increased by callus culture.

In the present study, three different plant growth regulator combinations were tested, and at the end of the study, the first medium combination, which had $0.1 \mathrm{mg} \mathrm{L}^{-1} \mathrm{NAA}$ and $0.2 \mathrm{mg} \mathrm{L}^{-1} \mathrm{Kin}$, was found to be more successful than the other two medium combinations for the anthocyanin production. In terms of the two different UV-C irradiation times (10-15 $\mathrm{min}$ ), both periods were effective in increasing the anthocyanin production; however, the $10 \mathrm{~min}$ irradiation was the prominent time with its positive effect on anthocyanin production. When the effect of incubation times was evaluated, it was determined that the anthocyanin production increased generally within the $24^{\text {th }}$ hour when compared to the initial value; however, it was possible to reach the highest anthocyanin content that was obtained at the end of the study at the $72^{\text {nd }}$ hour, which was the latest incubation time.

Finally, when the results of the study were evaluated in terms of callus age, the 12 day old calli were more successful than 15 day old. As a result of the study, it may be concluded that the content of the medium, elicitor application, and application time are effective on the callus culture and anthocyanin production in grapevines.

\section{Acknowledgments}

We are grateful for the financial support provided for this research by Van Yüzüncü Y1l University
Scientific Research Project Coordination (FYL2017-5934).

\section{References}

Abbasi, B.H., Stiles, A.R., Saxena, P.K., Liu, C.Z., 2012. Gibberellic acid increases secondary metabolite production in Echinacea purpurea hairy roots. Applied Biochemistry and Biotechnology, 168: 2057-2066.

Barz, W., Daniel, S., Hindeer, W., Jaques, U., Kessman H, Koster J, Otto C, Tiemann K., 1988. Plant Cell Biotechnology. M.S.S. Pais, F. Mavituna, J.M. Novais (Eds.), Elicitation and metabolism of phytoalexins in plant cell cultures, NATO ASI Series (Series H: Cell Biology), Vol 18, Springer, Berlin, Heidelberg.

Bhagyalakshmi, N., Thimmaraju, R., Narayan, M.S., 2004. Various hexoses and di-hexoses differently influence growth, morphology and pigment synthesis in transformed root cultures of red beet (Beta vulgaris). Plant Cell, Tissue and Organ Culture, 78(2): 183-195.

Blando, F., Scardino, A.P., De Bellis, L., Nicoletti, I., Giovinazzo, G., 2005. Characterization of in vitro anthocyanin producing sour cherry (Prunus cerasus L.) callus cultures. Food Research International, 38: 937-942.

Canturk, S., Kunter, B., Çoksarı, G., 2018. Effects of kaolin and dicarboxylic acid based stress inhibitors on aroma composition of two table grape cultivars (Vitis vinifera L.). Acta Scientiarum Polonorum Hortorum Cultus, 17(5): 37-46.

Cardoso, J.C., De Oliveira, M.E.B, De CI Cardoso, F., 2019. Advances and challenges on the in vitro production of secondary metabolites from medicinal plants. Horticultura Brasileira, 37(2): 124-132.

Çetin, E.S., Babalık, Z., Göktürk Baydar, N., 2012. Bazı sofralık üzüm çeşitlerinde tanelerdeki toplam karbonhidrat, fenolik madde, antosiyanin, $\beta$-karoten ve $\mathrm{C}$ vitamini içeriklerinin belirlenmesi. $I V$. Ulusal Üzümsü Meyveler Sempozyumu, 3-5 Ekim, Antalya, s. 151-156.

Çetin, E.S., Uzunlar, F., Göktürk Baydar, N., 2011. UVC uygulamasının Gamay üzüm çeşidine ait kalluslarda sekonder metabolit üretimi üzerine etkileri. Guda, 36(6): 319-326.

Demirci., T., Özdamar, P., Göktürk Baydar, N., 2015. Tibbi ve aromatik bitkiler ile sebzelerde kök kaynaklı sekonder metabolitlerin üretiminin artırılmasına yönelik in vitro uygulamalar. Turkish Journal of Agriculture-Food Science and Technology, 3(5): 261-270.

Eibl, R., Meier, P., Stutz, I., Schildberger, D., Hühn, T., Eibl, D., 2018. Plant cell culture technology in the cosmetics and food industries: current state and future trends. Applied Microbiology and Biotechnology, 102(20): 8661-8675.

Gamborg, O., Miller, R, Ojima, K., 1968. Nutrient requirement suspensions cultures of soybean root cells. Experimental Cell Research, 50(1): 151-158. 
Grassmann, J., Hippeli, S., Elstner, E.F., 2002. Plant's de-fence and its benefits for animals and medicine: role of phenolics and terpenoids in avoiding oxygen stress. Plant Physiology and Biochemistry, 40: 471478.

Gundlach, H., Muller, J.M., Kuthan, T.M., Zenk, M.H., 1992. Jasmonic acid is a signal transducer in elicitor induced plant cell cultures. Plant Biology, 89(6): 2389-2393.

Harborne, J.B., 2001. Twenty-five years of chemical ecology. Natural Product Reports, 18: 361-379.

Iercan, C., Nedelea, G., 2012. Experimental results concerning the effect of culture medium $\mathrm{pH}$ on the synthesized anthocyanin amount in the callus culture of Vitis vinifera L. Journal of Horticulture, Forestry and Biotechnology, 16(2): 71-73.

Karataş, İ., Elmastaş, M., Karataş, R., 2014. Siyah havuç (Daucus carota ssp. sativus var. atrorubens Alef) kallus kültüründe antosiyanin üretimine bazı uygulamaların etkisi. Gaziosmanpaşa Bilimsel Araştırma Dergisi, 9: 62-73.

Keskin, N., Kunter, B., 2007. Erciş üzüm çeşidinin kallus kültürlerinde UV 1şını etkisiyle resveratrol üretiminin uyarılması. Tarım Bilimleri Dergisi, 13(4): 379-384.

Keskin, N., Kunter, B., 2008. Production of transresveratrol in 'Cabernet Sauvignon' (Vitis vinifera $\mathrm{L}$.) callus culture in response to ultravioletC irradiation. Vitis, 47(4): 193-196.

Keskin, N., Kunter, B., 2009. The effects of callus age, UV irradiation and incubation time on transresveratrol production in grapevine callus culture. Journal of Agricultural Sciences, 15(1): 9-13.

Keskin, N., Kunter, B., 2010. Production of transresveratrol in callus tissue of Öküzgözü (Vitis vinifera L.) in response to ultraviolet-C irradiation. The Journal of Animal and Plant Sciences, 20(3): 197-200.

Khatami, F., Ghanati, F., 2011. Effects of UV irradiation on cell viability, anthocyanin, and flavonoid contents of callus-cultured Malva neglecta cells. International Conference on Life Science and Technology, 3: 198-201.

Lazăr, A., Petolescu, C., Peev, C., 2013. Interrelations between anthocyanins quantity synthetized in callus culture and the period of cultivation at Vitis vinifera L. Romanian Biotechnological Letters, 18(4): 84678474.

Luczkiewicz, M., Cisowski, W., 2001. Optimisation of the second phase of a two phase growth system for anthocyanin accumulation in callus cultures of Rudbeckia hirta. Plant Cell Tissue Organ Culture, 65: 57-68.
Matkowski, A., 2008. Plant in vitro culture for the production of antioxidants-A review. Biotechnology Advences, 26(6): 548-560.

Meng, X.C., Peng, J.Z., Wang, X.J., 2007. Anthocyanin accumulation and CHS, DFR gene expression regulated by light and sugar in Gerbera hybrida Ray Floret. Acta Horticulturae, 34: 227-230.

Mihai, R., Brezeanu, A., Cogalniceanu, G., 2009. Aspects of some elicitors influence on nonmorphogenic callus of Vitis vinifera var. Isabelle. Romanian Biotechnological Letters, 14(4): 4511-4518.

Mihai, R., Mitoi, M., Brezeanu, A., Cogalniceanu, G., 2010. Two-stage system, a possible strategy for the enhancement of anthocyanin biosynthesis in a longterm grape callus cultures. Romanian Biotechnological Letters, 15(1): 5026-5033.

Miura, H., Kitamura, Y., Ikenaga, T., Mizobe, K., Shimizu, T., Nakamura, M., 1998. Anthocyanin production of Glehnia littoralis callus cultures. Phytochemistry, 48(2): 279-283.

Mulabagal, V.M., Tsay, H.S., 2004. Plant cell cultures an alternative and efficient source for the production of biologically important secondary metabolites. International Journal of Applied Science and Engineering, 2: 29-48.

Murashige, T., Skoog, F., 1962. A revised medium for rapid growth and bioassays with tobacco tissue cultures. Physiologia Plantarum, 15: 473-497.

Sökmen, A., Gürel, E., 2001. Sekonder metabolit üretimi. M. Babaoğlu, E. Gürel, S. Özcan (Ed.), Bitki Biyoteknolojisi, Doku Kültürü ve Uygulamaları, Selçuk Üniversitesi Vakfı Yayınları, Konya, s. 211-261.

Stintzing, F.C., Carle, R., 2004. Functional properties of anthocyanins and betalains in plants, food, and in human nutrition. Trends in Food Science and Technology, 15(1): 19-38.

Tamura, H., Kumaoka, Y., Sugisawa, H. 1989. Identification and quantitative variation of anthocyanins produced by cultured callus tissue of Vitis sp. Agricultural and Biological Chemistry, 53(7): 1969-1970.

Tarrahi, R., Rezanejad, F., 2013. Callogenesis and production of anthocyanin and chlorophyll in callus cultures of vegetative and floral explants in Rosa gallica and Rosa hybrida (Rosaceae). Turkish Journal of Botany, 37: 1145-1154.

Verpoorte, R., Contin, A., Memelink, J., 2002. Biotechnology for the production of plant secondary metabolites. Phytochemistry Reviews, 1: 13-25. 